\title{
SYNTHESIS AND ANTIBACTERIAL ACTIVITY OF NOVEL 3- HYDROXY BENZOIC ACID HYBRID DERIVATIVES [PART II]
}

\author{
Maruti S. Satpute ${ }^{1}$, Vijay D. Gangan ${ }^{2, *}$ and Indu Shastri ${ }^{3}$ \\ ${ }^{1}$ Department of Chemistry, R. D. National College and W. A. Science College, Linking \\ Road, Bandra (W), Mumbai-400050. \\ ${ }^{2}$ Department of Chemistry, Loba R \& D Centre, Loba Chemie Pvt. Ltd., Plot No. D - 22, \\ Tarapur MIDC, Boisar, Palghar-401506, India. \\ ${ }^{3}$ Department of Chemistry, R. D. National College and W. A. Science College, Linking \\ Road, Bandra (W), Mumbai-400050. \\ E-mail: vijaygangan67@gmail.com
}

\begin{abstract}
3-hydroxy benzoic acid is an organic chemical which can be obtained naturally as well as synthetically. The literature survey reveals its various biological properties viz. antimicrobial, antialgal, antimutagenic, antiestrogenic, hypoglycemic, anti-inflammatory, anti-platelet aggregating, nematicidal, antiviral, antioxidant etc. It is also reported to be used as a preservative in many drugs, cosmetic products, pharmaceuticals, food and beverages. Some derivatives of 3-hydroxybenzoic acid are found to possess direct action on Hbs molecules, inhibit acetic acidinduced oedema and used in the management of sickle cell disease. It also has wide applications in perfumery industries. In this paper, novel ester / hybrid derivative of 3-Hydroxy benzoic acid was synthesized and tested for its potential antibacterial activity. This combinatorial synthesis of novel 3-Hydroxy benzoic ester/hybrid derivative can be a useful approach to generate potent chemotherapeutic agents in developing new drug candidates.

Keywords: 3-Hydroxy Benzoic Acid, IR, ${ }^{1} \mathrm{HNMR}$, TOF MS, DCC, DMAP, Biological Activities, Antibacterial, Agar Cup Method.
\end{abstract}

(C) RASĀYAN. All rights reserved

\section{INTRODUCTION}

Phenolic compounds exist in most plant tissues as secondary metabolites, i.e. they are not essential for growth, development or reproduction but may play roles as antioxidants and in interactions between the plant and its biological environment. Phenolics are also important components of the human diet due to their potential antioxidant activity, their capacity to diminish oxidative stress induced tissue damage resulted from chronic diseases, and their potentially important properties such as anticancer activities ${ }^{1-5}$. 3-Hydroxybenzoic acid is found in common plants such as grapefruit (Citrus paradisi), olive oil (Olea europaea), and medlar fruit (Mespilus germanica) $)^{6,7}$. It has glucosylating activity ${ }^{8}$. 3-Hydroxy benzoic acid is a naturally occurring active compound having antimicrobial, anti-inflammatory and antioxidant/anticancer properties, in continuation to our earlier work we thought of synthesizing compounds with novel ether, ester and hybrid derivatives of 3-hydroxy benzoic acid wherein 3-hydroxy benzoic acid would be etherified, esterified and hybridized with various other compounds and to check whether these compounds possess above biological activities ${ }^{8-18}$. The objective of this study is to condense two molecules of the same disease domain to produce more potent candidate in the same disease domain or to condense two molecules of different disease domain to produce a mixed variety of those disease domain or to have drug candidate with entirely different biological activity.

\section{EXPERIMENTAL}

Melting points were determined on a Thomas Hoover capillary melting point apparatus using a digital thermometer. IR spectra were recorded on a Shimadzu FTIR Prestige model as $\mathrm{KBr}$ pellet. ${ }^{1} \mathrm{H}$ NMR

Rasayan J. Chem., 12(3), 1077-1084(2019)

http://dx.doi.org/10.31788/RJC.2019.1235167

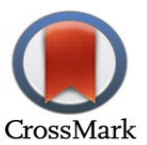


spectra were recorded on a Varian $200 \mathrm{MHz}$ spectrometer in $\mathrm{CDCl}_{3}$. Chemical shifts were recorded in parts per million downfield from tetramethylsilane. Mass spectra were recorded on a TOF MS ES mass spectrometer. Elemental analysis was carried out as a percentage on a Thermo Finnigan, Flash EA 1112 series, Italy.

\section{Materials and Methods}

Chemicals used were of a laboratory grade. The reactions were monitored by TLC on aluminum-backed silica plate visualized by UV-light.

\section{RESULTS AND DISCUSSION}

Preparation of 3-methoxy benzoic acid :- 3-hydroxybenzoic acid (1) was subjected to esterification using ( $\mathrm{MeOH} /$ Conc. $\mathrm{H}_{2} \mathrm{SO}_{4}, 8$ hrs.) to yield 3-hydroxy methyl benzoate (2) which were subjected to etherification with various alkyl halides $\left(\mathrm{K}_{2} \mathrm{CO}_{3} /\right.$ Acetone / Reflux, $\left.6-8 \mathrm{hrs}\right)$ to yield 3-alkoxy methyl benzoate (3) derivatives which were purified by column chromatography. These purified ether derivatives were subjected to hydrolysis using $10 \% \mathrm{Aq}$. $\mathrm{KOH}$ in $\mathrm{MeOH}$ followed by precipitation with dil. $\mathrm{HCl}$ at 10 $-15^{\circ} \mathrm{C}$ to yield off white ppt. of 3-alkoxy benzoic acids $(4-6)$ quantitatively. They were filtered through Buchner funnel, wash with water till neutral, suck dry and finally dried in an oven at $70^{\circ} \mathrm{C}$ for 12 hrs. Their structures were unambiguously confirmed by IR, ${ }^{1} \mathrm{H}$ NMR, Mass spectroscopy and elemental analysis.

Reaction Scheme 1 :

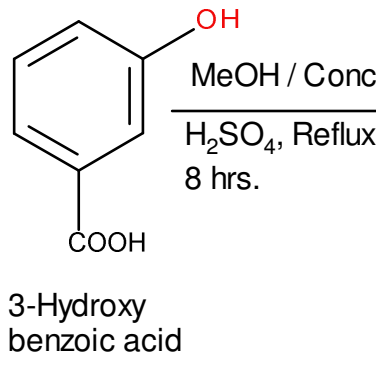

(1)

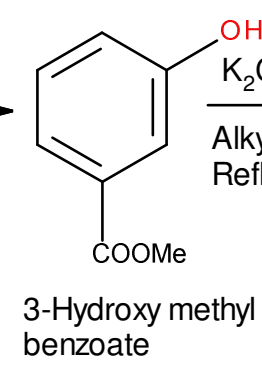

(2)

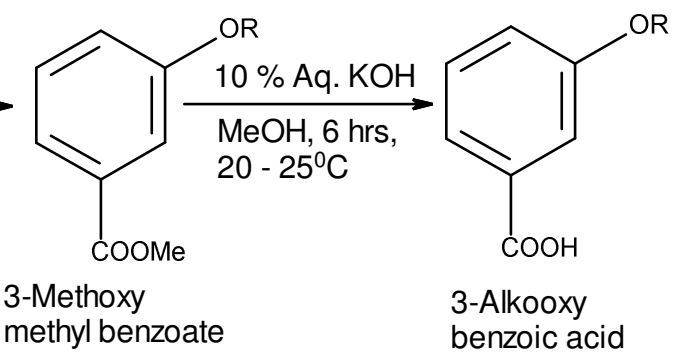

(3)
(4)

Scheme-1

where $\mathrm{R}=$ butyl (4), pentyl (5), hexyl (6)

Above 3-alkoxy benzoic acids were then condensed with 3-Hydroxy methyl benzoate under DCC / DMAP / Pyridine condition in dichloromethane to yield desired hybrid derivatives $(7,8,9)$ respectively whose structures were unambiguously confirmed by IR, ${ }^{1} \mathrm{H}$ NMR, Mass spectroscopy and elemental analysis and tested for their potential antimicrobial activity.

\section{Synthesis of Fused Molecules(7-9)}

These were prepared by following the general method as depicted below.

To a stirred solution of 3-Hydroxy methyl benzoate [A] (1 eq.) in $30 \mathrm{ml}$ dichloromethane was added DCC [C] (1.3 eq.), DMAP [D] (0.05 eq.), pyridine [E] (0.5 eq.) and the reaction mixture stirred at room temperature for $5 \mathrm{~min}$. A clear solution of the reaction mixture was obtained. To this, compound [B] aromatic / substituted aromatic acid (1.3 eq.) was added and stirring continued at room temperature for the next 8 hrs. As the reaction proceeds, urea derivative precipitates out as a by-product. The progress of the reaction was monitored by TLC for completion of the reaction.

\section{Work Up}

The reaction mixture filtered through celite bed which gets rids of by-product urea derivative. The filtrate was concentrated to minimum, preadsorbed on silica gel $(100-200$ mesh) and purified by column 
chromatography with an increase in the concentration of ethyl acetate in petroleum ether. The general yields of these reactions range between $70-80 \%$. This is another method of preparing esters and follows green chemistry parameters.

The most significant features of this methodology are (a) good accessibility of the reagent and its stability (b) a stoichiometric amount of reagent can be used by direct weighing, avoiding excess (c) no evolution of hazardous vapors during the reaction (d) the total elimination of the use of toxic organic solvents (e) a simple experimental procedure $(\mathrm{g})$ good control over the outcome of the reaction by varying the amount of reagent (h) less expensive. The aforesaid protocol thus provides an improved procedure for the synthesis of useful hybrid derivatives having important pharmaceutical, agricultural and other physicochemical properties.

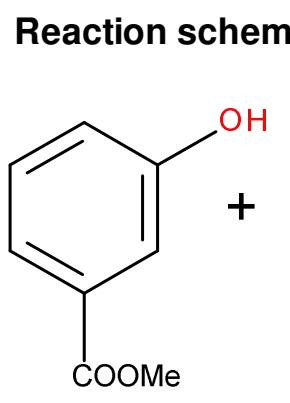

(A)

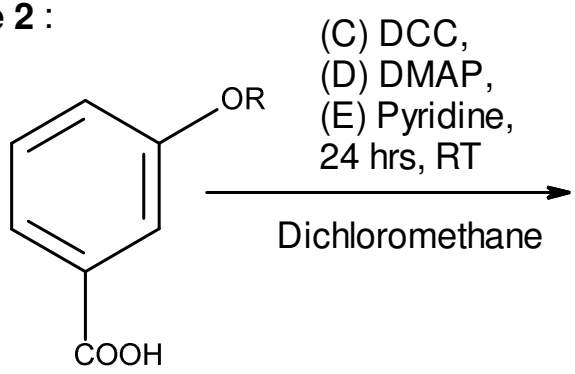

(B)
S. No. 1 3-Hydroxy methyl benzoate (2) 2 3-Hydroxy methyl benzoate (2) 3 3-Hydroxy methyl benzoate (2)

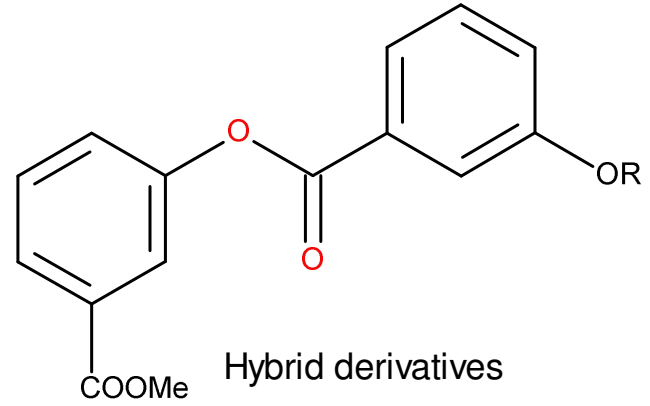

where $R=$ butyl (7), pentyl (8), hexyl (9)
3-Butoxybenzoic acid (4)

3-Pentoxybenzoic acid (5)

3-Hydroxybenzoic acid (6)

$$
\begin{gathered}
\text { Product (R) } \\
-\mathrm{C}_{4} \mathrm{H}_{9}(7) \\
-\mathrm{C}_{5} \mathrm{H}_{11}(8) \\
-\mathrm{C}_{6} \mathrm{H}_{13}(9)
\end{gathered}
$$

Characterization of Compounds (4) to (9)

Scheme-2

\section{3-Butoxybenzoic acid (4)}

${ }^{1} \mathrm{H}$ NMR $\left(\mathrm{CDCl}_{3}, 200 \mathrm{MHz}\right) \delta \mathrm{ppm}: 1.042\left(\mathrm{t}, \mathrm{J}=6.2 \mathrm{~Hz}, 3 \mathrm{H},-\mathrm{CH}_{3}\right.$, terminal methyl from butyl bromide moiety), $1.40-1.70\left(\mathrm{~m}, 2 \mathrm{H}, 1 \mathrm{x}-\mathrm{CH}_{2}\right.$ from butyl bromide moiety), $1.70-1.90\left(\mathrm{~m}, 2 \mathrm{H}, 1 \mathrm{x}-\mathrm{CH}_{2}\right.$ from butyl bromide moiety), $4.040\left(\mathrm{t}, \mathrm{J}=6.6 \mathrm{~Hz}, 2 \mathrm{H}, 1 \mathrm{x}-\mathrm{OCH}_{2}\right.$ group), $7.0-7.8(\mathrm{~m}, 4 \mathrm{H}, \mathrm{ArH}), 10.749$ (broad hump, 1H, - $\mathrm{OH}, \mathrm{D}_{2} \mathrm{O}$ exchangeable); IR (KBr) $\mathrm{cm}^{-1}$ :- 2954, 2937, 2871 (methyls, methylenes, methines), $2670-2500$ (-OH stretching of $-\mathrm{COOH}$ group), 1684 (acid carbonyl $>\mathrm{C}=\mathrm{O}$ group), $1601-$ 1582 (aromatic); TOF MS ES: $217(\mathrm{M}+\mathrm{Na})$; Molecular Formula $\mathrm{C}_{11} \mathrm{H}_{14} \mathrm{O}_{3}$; Melting range $59-$ $61^{\circ} \mathrm{C}$; Elemental Analysis, Calcd.: C $67.97 \%, \mathrm{H} 7.33 \%$, O $24.70 \%$. Found C $67.95 \%$, H $7.35 \%$, O $24.71 \%$.

\section{3-Pentoxybenzoic Acid (5) \\ ${ }^{1} \mathrm{H}$ NMR $\left(\mathrm{CDCl}_{3}, 200 \mathrm{MHz}\right) \delta \mathrm{ppm}: 0.993\left(\mathrm{t}, \mathrm{J}=7.2 \mathrm{~Hz}, 3 \mathrm{H},-\mathrm{CH}_{3}\right.$, terminal methyl from pentyl bromide moiety), $1.20-1.60\left(\mathrm{~m}, 4 \mathrm{H}, 2 \mathrm{x}-\mathrm{CH}_{2}\right.$ from pentyl bromide moiety), $1.60-1.90(\mathrm{~m}, 2 \mathrm{H}, 1 \mathrm{x}-$ $\mathrm{CH}_{2}$ from pentyl bromide moiety), $4.030\left(\mathrm{t}, \mathrm{J}=6.4 \mathrm{~Hz}, 2 \mathrm{H}, 1 \mathrm{x}-\mathrm{OCH}_{2}\right.$ group), $7.1-7.8(\mathrm{~m}, 4 \mathrm{H}, \mathrm{ArH})$, 10.289 (broad hump, 1H, - OH, $\mathrm{D}_{2} \mathrm{O}$ exchangeable); IR (KBr) cm $\mathrm{cm}^{-1}$ :- 2951, 2913, 2892, 2870, 2848 (methyl, methylenes, methines), $2700-2500$ (-OH stretching of $-\mathrm{COOH}$ group), 1684 (acid carbonyl $>\mathrm{C}=\mathrm{O}$ group), $1600-1587$ (aromatic); TOF MS ES: $231\left(\mathrm{M}+\mathrm{Na}\right.$ ); Molecular Formula $\mathrm{C}_{12} \mathrm{H}_{16} \mathrm{O}_{3}$; Melting range $96-100^{\circ} \mathrm{C}$; Elemental Analysis, Calcd.: C $69.18 \%, \mathrm{H} 7.72 \%$, O $23.10 \%$. Found C 69.21 $\%, \mathrm{H} 7.79 \%$, O $23.08 \%$.}

\section{3-Hexoxybenzoic Acid (6)}

${ }^{1} \mathrm{H}$ NMR $\left(\mathrm{CDCl}_{3}, 200 \mathrm{MHz}\right) \delta \mathrm{ppm}: 0.925\left(\mathrm{t}, \mathrm{J}=6.4 \mathrm{~Hz}, 3 \mathrm{H},-\mathrm{CH}_{3}\right.$, terminal methyl from hexyl bromide moiety), $1.10-1.60$ (m, $6 \mathrm{H}, 3 \mathrm{x}-\mathrm{CH}_{2}$ from hexyl bromide moiety), $1.60-1.90(\mathrm{~m}, 2 \mathrm{H}, 1 \mathrm{x}-$ 
$\mathrm{CH}_{2}$ from hexyl bromide moiety), $4.026\left(\mathrm{t}, \mathrm{J}=6.4 \mathrm{~Hz}, 2 \mathrm{H}, 1 \mathrm{x}-\mathrm{OCH}_{2}\right.$ group), 5.324 (broad hump, 1H, $\mathrm{OH}, \mathrm{D}_{2} \mathrm{O}$ exchangeable), 7.1 - 7.8 (m, 4H, ArH); IR (KBr) cm ${ }^{-1}$ :- 2955, 2902, 2867 (methyl, methylenes, methines), $2676-2565$ (-OH stretching of $-\mathrm{COOH}$ group), 1677 (acid carbonyl $>\mathrm{C}=\mathrm{O}$ group), $1601-$ 1586 (aromatic); TOF MS ES: $245\left(\mathrm{M}+\mathrm{Na}\right.$ ); Molecular Formula $\mathrm{C}_{13} \mathrm{H}_{18} \mathrm{O}_{3}$; Melting range $112-$ $115^{\circ} \mathrm{C}$; Elemental Analysis, Calcd.: C $70.18 \%$, H $8.22 \%$, O $21.60 \%$. Found C $70.21 \%$, H 8.19 \%, O $21.58 \%$.

\section{(3-methoxycarbonylphenyl) 3-butoxybenzoate (7)}

${ }^{1} \mathrm{H}$ NMR $\left(\mathrm{CDCl}_{3}, 200 \mathrm{MHz}\right) \delta \mathrm{ppm}: 0.96(\mathrm{t}, \mathrm{J}=7.2 \mathrm{~Hz}, 3 \mathrm{H}$, terminal methyl from butyl bromide moiety), $1.3-1.6\left(\mathrm{~m}, 4 \mathrm{H}, 2 \mathrm{x}-\mathrm{CH}_{2}\right.$ from butyl bromide moiety), $1.6-1.9\left(\mathrm{~m}, 2 \mathrm{H}, 1 \mathrm{x}-\mathrm{CH}_{2}\right.$ from butyl bromide moiety), 3.94 (s, 3H, 1 x Ar-COOCH 3 group), 4.045 (t, $\mathrm{J}=6.4 \mathrm{~Hz}, 2 \mathrm{H}, 1 \mathrm{x}-\mathrm{OCH}_{2}$ group), 7.1 - 8.0 (m, 8H, ArH); IR (KBr) $\mathrm{cm}^{-1}$ :- 2952, 2934 (methyls, methylenes, methines), 1726 - 1685 (ester carbonyls $>\mathrm{C}=\mathrm{O}$ ), 1615 - 1584 (aromatic); TOF MS ES: $351(\mathrm{M}+\mathrm{Na})$; Molecular Formula $\mathrm{C}_{19} \mathrm{H}_{20} \mathrm{O}_{5}$; Off white solid; Melting range $66-70^{\circ} \mathrm{C}$; Elemental Analysis, Calcd.: $\mathrm{C} 69.48 \%, \mathrm{H} 6.12 \%$, O $24.40 \%$. Found C $69.51 \%$, H $6.09 \%$, O $24.39 \%$.

\section{(3-methoxycarbonylphenyl) 3-pentoxybenzoate (8)}

${ }^{1} \mathrm{H}$ NMR $\left(\mathrm{CDCl}_{3}, 200 \mathrm{MHz}\right) \delta \mathrm{ppm}: 1.006(\mathrm{t}, \mathrm{J}=7.2 \mathrm{~Hz}, 3 \mathrm{H}$, terminal methyl from pentyl bromide moiety), $1.1-1.4\left(\mathrm{~m}, 2 \mathrm{H}, 1 \mathrm{x}-\mathrm{CH}_{2}\right.$ from pentyl bromide moiety), $1.4-1.7$ (m, $2 \mathrm{H}, 1 \mathrm{x}-\mathrm{CH}_{2}$ from pentyl bromide moiety), $1.7-2.0$ (m, $2 \mathrm{H}, 1 \mathrm{x}-\mathrm{CH}_{2}$ from pentyl bromide moiety), 3.94 (s, 3H, $1 \mathrm{x} \mathrm{Ar}-\mathrm{COOCH}$ group), $4.054\left(\mathrm{t}, \mathrm{J}=6.6 \mathrm{~Hz}, 2 \mathrm{H}, 1 \mathrm{x}-\mathrm{OCH}_{2}\right.$ group), $7.1-8.0(\mathrm{~m}, 8 \mathrm{H}, \mathrm{ArH})$; IR (KBr) cm ${ }^{-1}$ :- 2952, 2934 (methyls, methylenes, methines), 1726 - 1685 (ester carbonyls $>\mathrm{C}=\mathrm{O}$ ), 1615 - 1584 (aromatic); TOF MS ES: $365(\mathrm{M}+\mathrm{Na})$; Molecular Formula $\mathrm{C}_{20} \mathrm{H}_{22} \mathrm{O}_{5}$; Reddish yellowish crystals; Melting range 57 $-65^{\circ} \mathrm{C}$; Elemental Analysis, Calcd.: C $70.18 \%$, H $6.52 \%$, O $23.30 \%$. Found C $70.21 \%$, H $6.49 \%$, O $23.28 \%$.

\section{(3-methoxycarbonylphenyl) 3-hexoxybenzoate (9)}

${ }^{1} \mathrm{H}$ NMR $\left(\mathrm{CDCl}_{3}, 200 \mathrm{MHz}\right) \delta \mathrm{ppm}: 0.924(\mathrm{t}, \mathrm{J}=6.8 \mathrm{~Hz}, 3 \mathrm{H}$, terminal methyl from hexyl bromide moiety), $1.2-1.7$ (m, $6 \mathrm{H}, 3 \mathrm{x}-\mathrm{CH}_{2}$ from hexyl bromide moiety), $1.7-2.0\left(\mathrm{~m}, 2 \mathrm{H}, 1 \mathrm{x}-\mathrm{CH}_{2}\right.$ from hexyl bromide moiety), $1.7-2.0\left(\mathrm{~m}, 2 \mathrm{H}, 1 \mathrm{x}-\mathrm{CH}_{2}\right.$ from hexyl bromide moiety), 3.94 (s, 3H, 1 x Ar-COOCH group), 4.044 (t, J = 6.4 Hz, 2H, $1 \mathrm{x}-\mathrm{OCH}_{2}$ group), $7.1-8.0(\mathrm{~m}, 8 \mathrm{H}, \mathrm{ArH}) ; \mathrm{IR}(\mathrm{KBr}) \mathrm{cm}^{-1}$ :- 2952, 2934 (methyls, methylenes, methines), 1726 - 1685 (ester carbonyls $>\mathrm{C}=\mathrm{O}$ ), 1616 - 1585 (aromatic); TOF MS ES: $379(\mathrm{M}+\mathrm{Na})$; Molecular Formula $\mathrm{C}_{21} \mathrm{H}_{24} \mathrm{O}_{5}$; Pale pink crystals; Melting range $110-$ $112^{0} \mathrm{C}$; Elemental Analysis, Calcd.: C $70.80 \%$, H $6.80 \%$, O $22.40 \%$. Found C $70.78 \%$, H $6.82 \%$, O $22.28 \%$.

\section{Chromatographic System \\ Column Chromatography}

For column chromatography 100 - 200 mesh Acme grade silica gel is used. The crude reaction mixture is concentrated under reduced pressure to yield crude mass which is preadsorbed on silica gel and purified by column chromatography with an increase in the concentration of Ethyl acetate in Petroleum ether. The fractions having similar ' $\mathrm{R}_{\mathrm{f}}$ ' values were pooled together, concentrated and subjected for characterization using various spectroscopic techniques.

\section{Thin Layer Chromatography}

TLC plates were prepared using silica gel G (ACME, BOMBAY). Pet. ether: EtOAc (85: 15) was used as the solvent system.

\section{Radial Chromatography}

The circular glass plates of thickness $1 \mathrm{~mm}$, were prepared by using silica gel (PF254, E. MERCK, $50 \mathrm{~g}$ ) in cold distilled water $(105 \mathrm{ml})$. For elution, gradually increasing concentrations of EtOAc in a pet. ether was employed. 
Probable mechanism for fused / hybrid molecules :

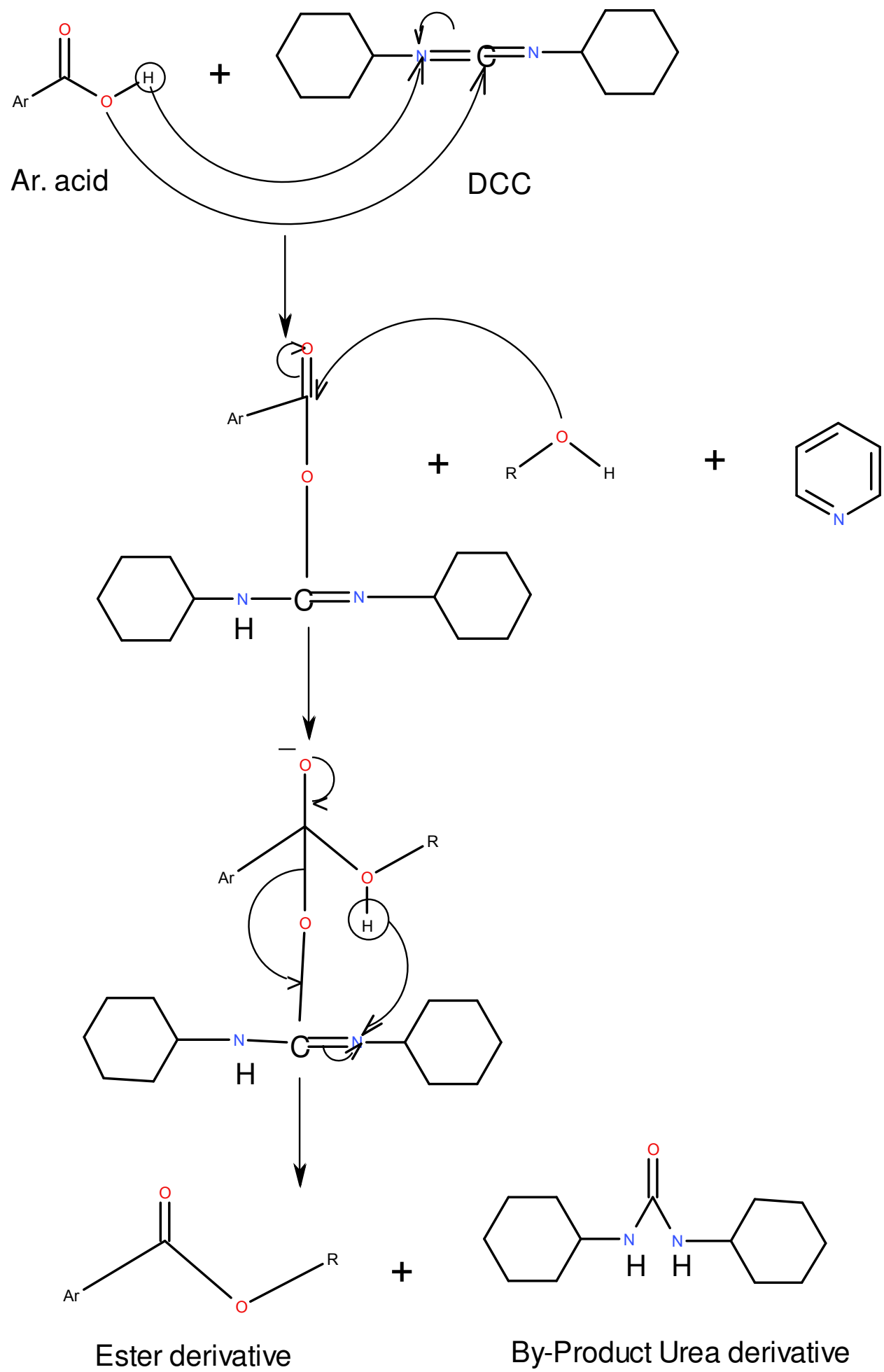

Scheme-3 
RASĀYAN J. Chem.

Vol. 12 | No. 3 |1077 - 1084| July - September | 2019

\section{Biological Activity}

Antibiotic Sensitivity Testing by the Agar Cup Method ${ }^{19-20}$

Diffusion assay technique is a standard method used to estimate the antibacterial activity of different antibiotics in fluids when tested against selected indicator bacterial strain.

The agar cup method can also be used for assays of antimicrobial agents in body fluids like a serum, CSF to determine whether therapeutic levels of antimicrobial agents have reached the likely sites of infection. This is especially important when chemotherapy fails to promote patient recovery even when the pathogen was shown to be sensitive to the drug used. Drug concentrations are also monitored in body fluids to see if an accumulation of the drug is occurring which might lead to potentially toxic concentrations and cause harmful side effects. The other main reason for measurement of antibiotics is to document that oral antibiotics are being absorbed from the gastrointestinal tract.

\section{Requirements}

St. MH agar butt (20 mL) - 2

St. petriplate - 2

St. $1 \mathrm{~mL}$ pipette -4

Standard antibiotic solutions $(7-9)$

St. Cork borer (external diameter $10 \mathrm{~mm}$ )

\section{Method}

Day-1

1. Inoculate $0.2 \mathrm{ml}$ of Staphylococcus aureus ATCC 6538 culture to $20 \mathrm{~mL}$ of cooled, melted MH Agar butt, mix and pour into a sterile plate. Allow it to solidify make 4 wells in each plate using a sterile cork borer. Transfer $0.1 \mathrm{~mL}$ of 4 different antibiotic solutions in each well of a plate aseptically using a micropipette. Place the plate in the refrigerator for $30 \mathrm{~min}$ for prediffusion of the antibiotic solutions. Incubate the plates at $37^{\circ} \mathrm{C}$ for $24 \mathrm{hrs}$.

2. Inoculate $0.2 \mathrm{ml}$ of Escherichia coli ATCC 8739 culture to $20 \mathrm{~mL}$ of cooled, melted $\mathrm{MH}$ Agar butt, mix and pour into a sterile plate. Allow it to solidify make 4 wells in each plate using a sterile cork borer. Transfer $0.1 \mathrm{~mL}$ of 4 different antibiotic solutions in each well of a plate aseptically using a micropipette. Place the plate in the refrigerator for $30 \mathrm{~min}$ for prediffusion of

Day-2 the antibiotic solutions. Incubate the plates at $37^{\circ} \mathrm{C}$ for $24 \mathrm{hrs}$.

Measure the diameter of zone of inhibition given by each antibiotic solution and interpret.

Note:

1. Presence of a haze of growth within the zone around the disc indicates drug resistance in the population of the isolate.

2. Quality control should be performed each time a new lot of discs or agar is used. NCCLS has established limits of zone size that are acceptable for quality control.

Table-1: Antibacterial Activity Results

Antibacterial activity of compounds (7 - 9) on Escherichia coli [Gram negative]

\begin{tabular}{c|c|c|c|c}
\hline \multirow{2}{*}{ S. No. } & Name of the compound & \multicolumn{2}{|c}{ Zone of inhibition (in mm) } \\
\cline { 3 - 4 } & 3-Hydroxy methyl benzoate (2) & 1 & 2 & $16 \mathrm{~mm}$ \\
\hline $2(\mathrm{~B})$ & $\begin{array}{c}\text { Base Molecule } \\
\text { (3-methoxycarbonylphenyl) 3- } \\
\text { butoxybenzoate (7) }\end{array}$ & $30 \mathrm{~mm}$ & $29 \mathrm{~mm}$ & $29.5 \mathrm{~mm}$ \\
\hline $3(\mathrm{C})$ & $\begin{array}{c}\text { (3-methoxycarbonylphenyl) 3- } \\
\text { pentoxybenzoate (8) }\end{array}$ & $31 \mathrm{~mm}$ & $33 \mathrm{~mm}$ & $32 \mathrm{~mm}$ \\
\hline $4(\mathrm{D})$ & $\begin{array}{c}\text { (3-methoxycarbonylphenyl) 3- } \\
\text { hexoxybenzoate (9) }\end{array}$ & $30 \mathrm{~mm}$ & $28 \mathrm{~mm}$ & $29 \mathrm{~mm}$ \\
\hline
\end{tabular}


RASĀYAN J. Chem.

Vol. 12 | No. 3 |1077 - 1084| July - September | 2019

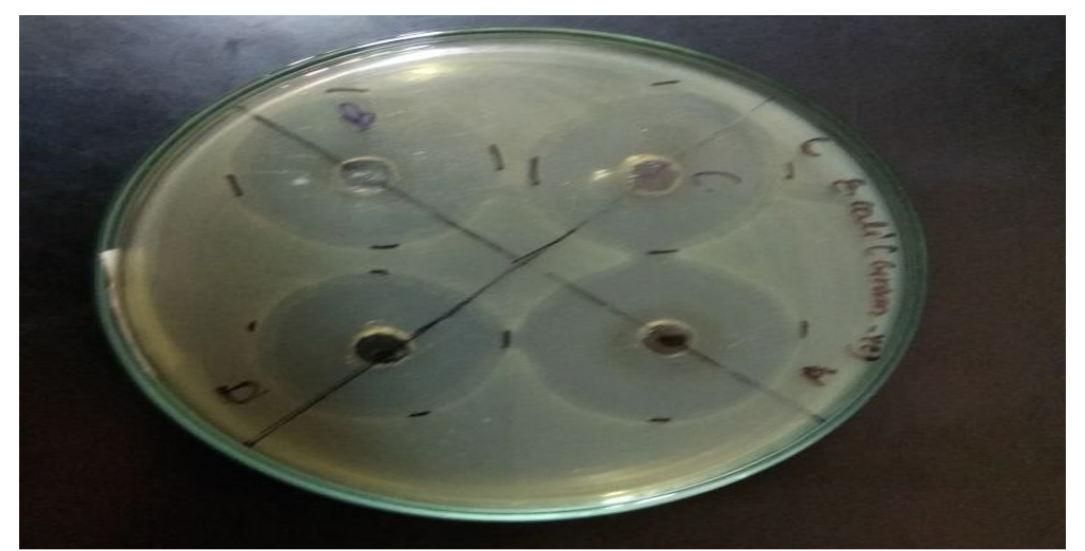

Fig. 1 . Antibacterial activity of compounds (7 - 9) on Escherichia coli [Gram negative]

Table-2: Antibacterial Activity Results

Antibacterial Activity of Compounds (7 - 9) on Staphylococcus aureus [Gram positive]

\begin{tabular}{c|c|c|c|c}
\hline \multirow{2}{*}{ S. No. } & Name of the compound & \multicolumn{2}{|c}{ Zone of inhibition (in mm) } \\
\cline { 3 - 4 } & $\begin{array}{c}\text { 3-Hydroxy methyl benzoate (2) } \\
\text { Base Molecule }\end{array}$ & $18 \mathrm{~mm}$ & $16 \mathrm{~mm}$ & $17 \mathrm{~mm}$ \\
\hline 2 (B) & $\begin{array}{c}\text { (3-methoxycarbonylphenyl) 3- } \\
\text { butoxybenzoate (7) }\end{array}$ & $27 \mathrm{~mm}$ & $28 \mathrm{~mm}$ & $27.5 \mathrm{~mm}$ \\
\hline $3(\mathrm{C})$ & $\begin{array}{c}\text { (3-methoxycarbonylphenyl) 3- } \\
\text { pentoxybenzoate (8) }\end{array}$ & $28 \mathrm{~mm}$ & $28 \mathrm{~mm}$ & $28 \mathrm{~mm}$ \\
\hline 4 (D) & $\begin{array}{c}\text { (3-methoxycarbonylphenyl) 3- } \\
\text { hexoxybenzoate (9) }\end{array}$ & $26 \mathrm{~mm}$ & $26 \mathrm{~mm}$ & $26 \mathrm{~mm}$ \\
\hline
\end{tabular}

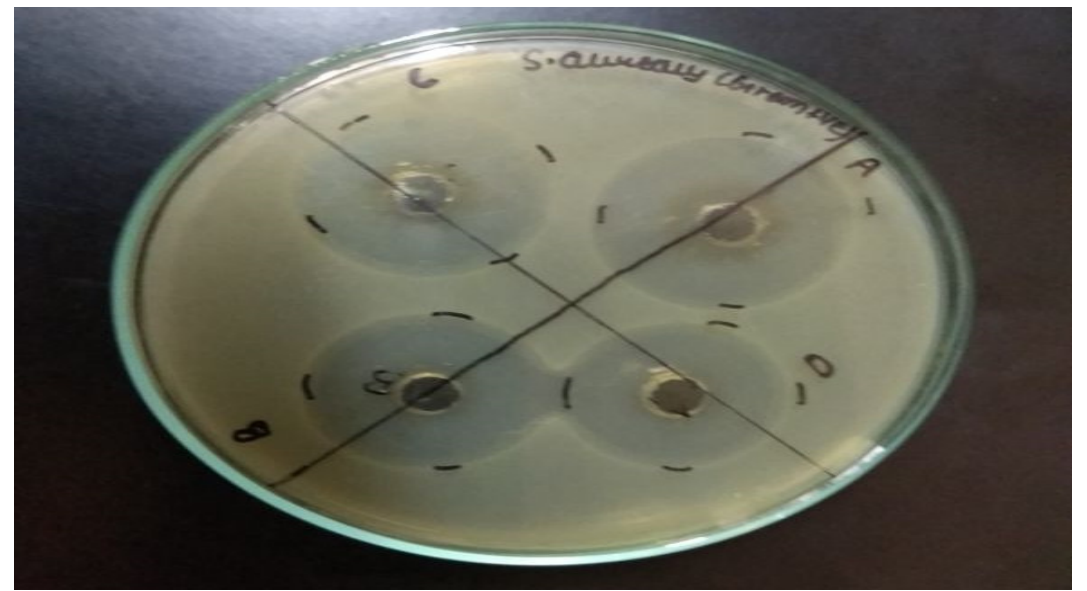

Fig.-2. Antibacterial Activity of Compounds (7 - 9) on Staphylococcus aureus [Gram positive]

\section{CONCLUSION}

The novel hybrid derivatives of 3-Hydroxy benzoic acid were synthesized by cost-effective industry viable process following the principles of green chemistry. The synthesis of hybrid derivatives was another way to prepare ester derivatives using DCC as a dehydrating agent in a reasonably good yield. The probable mechanism for the formation of hybrid derivative was also discussed.

The biological activity suggests that the base molecule 3-hydroxy methyl benzoate have anti-bacterial activity against both the bacterial cultures. Its derivatives viz. 7, 8, 9 were also active against both Gram + $v e$ and Gram-ve cultures. Thus, fused molecules of 3-Hydroxy benzoic acid (7 - 9) having alkyl side chain were potential antibacterial candidates. In-depth analysis of these compounds through structure-activity relationship studies would provide further insight and can be an interesting topic of future studies. 
RASĀYAN J. Chem.

Vol. 12 | No. 3 |1077 - 1084| July - September | 2019

The structural diversity and the pronounced biological activities encountered in the 3-hydroxy benzoic acid derivatives suggests that this class of compounds were worthy for further studies that may lead to derivatives by using combinatorial chemistry approach was an alternative strategy to new therapeutic discovery. In other words the generation of diverse 3-hydroxy benzoic acid derivatives develops new therapeutic molecules that might result in candidates having better activity. These synthesized hybrid derivatives were chemically new and confirmed by Sci-Finder search.

\section{ACKNOWLEDGMENT}

One of the authors Mr. Maruti S. Satpute thanks Dr. Indu Shastri, Research Guide and HOD, National College of Science and Commerce for suggesting a problem and constant valuable guidance throughout the course and providing laboratory facilities.

\section{REFERENCES}

1. K. R. Martin and C. L. Appel., Nutr. Dietary Suppl., 2, 1 (2010), DOI: 10.2147/NDS.S6422

2. L. Bravo, Nutr. Rev., 56(11), 317 (1998).

3. C. S. Harris, F. Mo, L. Migahed, L. Chepelev, P. S. Haddad, J. S. Wright, W. G. Willmore, J. T. Arnason and A. L. Bennett, Can. J. Physiol. Pharmacol., 85, 1124(2007), DOI: 10-1139/Y07-101.

4. W. Y., Huang, Y. Z. Cai and Y. Zhang, Nutr. Cancer, 62(1), 1 (2010), DOI: 10.1080/01635580903191585.

5. R. H. Liu, J. Nutr., 134, 3479S (2004).

6. A. Bendini, L. Cerretani, A. Carrasco-Pancorbo, A. M. Gomez-Caravaca, A. Segura-Carretero, A. Fernandez-Gutierrez and G. Lercker, Molecules, 12(8), 1679 (2007).

7. J. Gruz, F. A. Ayaz, H. Torun and M. Strnad, Food Chem., 124, 271(2011). DOI: $10.1016 /$ j.foodchem.2010.06.030

8. C. M. Ford and P. B. Hoj, Aust. J. Grape and Wine Res., 4, 48 (1998), DOI: 10.1111/j.17550238.1998.tb00134.x

9. H. W. Johnston, G.G. Briggs and M. Alexander, Soil Biology and Biochemistry, 4(2), 187 (1972), DOI: $10.1016 / 0038-0717(72) 90010-7$.

10. M. S. Satpute, I. Shastri and V. D. Gangan, Rasayan Journal of Chemistry, 12(1), 383 (2019), DOI: 10.31788/RJC.2019.1215023.

11. M. S. Satpute, I. Shastri and V. D. Gangan, International Journal of Scientific Research in Science and Technology, 4(11), 219 (2018), DOI :10.32628/IJSRST18401140

12. M. S. Satpute, I. Shastri and V. D. Gangan, International Journal for Research in Applied Science \& Engineering Technology, 6 (XII), 330 (2018).

13. V. D. Gangan and S. S. Sankhe, International Journal of Scientific Research in Science and Technology, 4(2), 886 (2018).

14. M. G. R. Priya, K. Girija and N. Ravichandran, Rasayan Journal of Chemistry, 4(2), 418 (2011) and the references cited theirin.

15. H. Pawar, N. Chaudhary, S. Singh. Rasayan Journal of Chemistry, 4(3), 498 (2011) and the references cited theirin.

16. A. K. Babu and K. Selvaraju, Rasayan Journal of Chemistry, 11(4), 1501 (2011) and the references cited theirin.

17. T. M. Siregar, E. Budianto, H. Cahyana and W. Wibowo, Rasayan Journal of Chemistry, 11(4), 1765 (2011) and the references cited theirin.

18. P. M. G. Swamy and Y. S. Agasimundin, Rasayan Journal of Chemistry, 3(2), 421 (2008) and the references cited theirin.

19. S. Singh, P. Chawla, V. Chawla and S. K. Saraf, Rasayan Journal of Chemistry, 6(3), 196 (2013) and the references cited theirin.

20. S. P. Hadke, T. T. Shelke, R. V. Antre, S. R. Wayal and S. N. Gaikwad, Journal of Current Pharma Research, 5(1), 1367 (2014).

[RJC-5167/2019] 